\title{
Business Strategy, Accounting Conservatism and Performance
}

\author{
$\mathrm{Han} \mathrm{Li}^{1}$ \\ ${ }^{1}$ SILC Business School, Shanghai University, Shanghai, China \\ Correspondence: Han Li, SILC Business School, Shanghai University, 20 Chengzhong Road, JiaDing District, \\ Shanghai 201800, China. E-mail: licn86@ hotmail.com
}

Received: February 14, 2020

Accepted: March 6, 2020

Online Published: March 20, 2020

doi:10.5430/afr.v9n2p23

URL: https://doi.org/10.5430/afr.v9n2p23

\begin{abstract}
This research is based on prior business strategy typology and accounting conservatism theories. It further investigates the joint effect of business strategy and accounting conservatism on the firm's financial performance. The paper finds that accounting conservatism as a prudent accounting reporting principle plays an important corporate governance mechanism. The conservatism can mitigate the negative effect of the aggressive business strategy. The joint effect between business strategy and accounting conservatism is positively related with financial performance. The result is robustness when the different measurements of the financial performance and the conservatism are applied. When the firm has weak internal control quality, the joint effect on financial performance also exists significantly.
\end{abstract}

Keywords: business strategy, accounting conservatism, financial performance

\section{Introduction}

Strategy should be firstly prepared and designed by the firms. Good strategy can build a comprehensive framework for the whole company's management. Some aggressive strategy that extending the market shares or investing the capital assets in a rather intensive way would bring much uncertainty in business. Accounting conservatism played as a kind of corporate governance mechanism can mitigate the negative effect of aggressive strategy companying with high ambiguity. This research is interested in finding whether the joint effect between business strategy and accounting conservatism would increase the financial performance. With the regression analysis, the paper finds that the intersection between business strategy and accounting conservatism is positively associated with financial performance. This result remains after considering the alternative measurement of the performance and conservatism. Furthermore, the research also testifies that the joint effect between business strategy and accounting conservatism is even significant especially under the weak internal control quality firms.

The behavior in the organization is predetermined by the external business environment and internal organization's structure and process. Business strategy can influence the organization's structure as well as the management process. Strategy is to set up the firm's long-term plan and to allocate all kinds of resources. Following with the strategy-choice theory, Miles and Snow $(1978,2003)$ apply the strategy typology for classifying different firm's strategies. There are four types of strategy: defenders, prospectors, analyzers and reactors. Defenders and prospectors are the opposite types with each other. The defenders' strategy is much centralized and rigid organization structure and wish to narrow the limited markets and products or services and to compete with the competitors mainly by improving the operating efficiency. However, the prospectors' strategy is likely to investigate new products or services and to enlarge the market shares by increasing the R\&D expenditure or similar capitalized assets. Navissi, et al. (2017) believe that the defenders involve much less risky investment. While, the prospectors are accompanying with much ambiguity and higher risk. Bentley et al. (2017) indicate that the prospectors have positively relationship with material weaknesses due to much more discretionary accounting treatments.

Accounting conservatism requires the firms to verify the losses quick than the gains. The asymmetric timeliness accounting treatments are applied in many countries' accounting principles. Watts (2003a, 2003b) and Sun and Xu (2012) think that accounting conservatism relates to debt contracting, litigation, regulation and policy, tax avoidance and management forecasts. Accounting conservatism is to reduce the information asymmetric between the internal and external shareholders. Especially, to report the financial statements in the prudent ways can satisfy the creditors' requirements. Accounting conservatism is always compulsory in the debt convents and to reduce the litigation costs for the creditors. From the equity-holders points of view, accounting conservatism can restrict the firm's management 
myopic behavior, such as investing the negative NPV projects or positive NPV but high risky projects (Lara,et al.,2016) and mitigate the financial constrains (Zhang and Wang, 2013). LaFond and Watts (2008) also express that accounting conservatism is an alternative corporate governance mechanism to benefit for the shareholder's wealth in the long run.

In line with the research of Hsu et al. (2017) and Lara et al. (2016), this research is interested in investigating the joint effect of business strategy and accounting conservatism on the financial performance in a firm. For the much higher strategy scores firms, they invest more in R\&D expenditures and extending the market shares. All these activities would bring much profit as well as more risk. The risk includes as follows: (1) financial risk, such as insolvency, cash flow liquidity problems; (2) weak internal control due to quite flexible management (3) operating risk, such as failure in $R \& D$ investment. Accounting conservatism can recognize the gains more quickly than the losses and play as a corporate governance mechanism to mitigate the possible negative effect of higher scores business strategy.

This paper shed light on the joint effect of strategy and conservatism that can be positively associated with financial performance. The result is robustness with different accounting conservatism and financial performance measurements. The joint effect on the financial performance relationship between strategy and conservatism is also found in the weak internal control firms. That proves that accounting conservatism can be an alternative governance method to improve the firm's performance.

This research contributes to the literature of business strategy and accounting conservatism. There are many researches involving in strategy and conservatism separately. Very few papers are making research in the economic effect of combining the business strategy and accounting conservatism. The result of this paper proves that business strategy is not just related to the firm's future development objectives but has good governance effect on the firm.

The remainder part of this paper is written as follows. Next part explains the related literature and develops hypothesis tests. Part 3 discusses the data collection and defines the variables. In the part 4 , the descriptive analysis and regression results are demonstrated. Part 5 makes a further robustness check. Last past contains the conclusions and further research suggestion.

\section{Literature Review and Hypothesis Development}

\subsection{Theories Review}

Strategy is to determine the firm's basic long-term objectives and the ways to achieve these objectives and how to allocate the firm's resources (Chandler,1962). Strategy is to influence the organization's behavior. The organization's behavior is predetermined by the environmental conditions. It is also an important factor to influence the organization's structure and process. Consistent with the strategic-choice theory, Miles and Snow $(1978,2003)$ interprets the strategy typology into four types: defenders, prospectors, analyzers and reactors. The defenders care about how to operate in a heavily cost-efficient way. A narrow market or a core technology is developed. More centralized and stable organization structure is appropriate for the defenders. To invest in less risky projects and under-investment are popular in the defenders (Navissi, et al.,2017). The prospectors do the opposite to the defenders. The prospectors are the creators of products or services in their industry. The prospectors are interested in facilitating the organizational operations with more decentralized and flexible structure (Miles et al.,1977). The market-oriented and innovation strategy motivate the managers to over-invest, even invest in the negative NPV projects or higher positive NPV but more risky projects (Navissi, et al., 2017). The managerial power and firm's cash holding would increase the positive relationship between the prospector's strategy and overinvestment (Wang, et al.,2016). Moreover, there are more accrual basis earnings management in the prospectors than in the defenders (Sun et al.,2016). Also, it is found that the prospectors contain less accounting conservative principles compared with the defenders (Liu, 2016). Unlike the defenders, the prospectors following discretionary managerial activities experience more material weaknesses (Bentley et al,2017), receive extra going concern opinion from the auditors (Yu et al., 2017), pay more audit fees with weaker internal control quality (Bentley et al.,2013) and engage in more tax avoidance (Higgins,et al., 2015).

Accounting conservatism is considered as an important accounting principle. Accounting conservatism principle requires the firms' recognition of the gains and losses in an asymmetric timeliness. With the conservatism requirements, the bad news is reflected in earnings more timely than good news. Furthermore, there must be much stricter verifiability for the recognition of gains compared with the losses (Basu,1997). Although there is a debate that the Financial Accounting Standards Board (FASB) in US and International Accounting Standards Board (IASB) asked for the removal of the accounting conservatism on the purpose of the neutral treatment of financial information 
in 2008 (note 1), the problems of accounting information quality under the uncertainty situations are always suggested to care about by those accounting standards board. (FASB,2005). In the line of conservatism research, many researches find that accounting conservatism matters for the debt contracting, litigation, tax and management forecast bias (Watts, 2003a,2003b; Sun and Xu,2012).Hsieh et al. (2019) find that in the face of ambiguity in business, it is rational to apply for the accounting conservatism. The reason that the lower verification thresholds about the potential decrease of cash flows than the future increase of cash flows is that the managers have different incentives to report the financial information about the losses and gains (Ball and Shivakumar,2005). When the firms apply for the timely verification losses, once the managers estimate ex ante that any project has potential losses in their tenure, the managers would be likely to reject those negative-NPV investments or high risky positive NPV investments; However, deferred recognition of losses would ignore the adjusted expected cash flows and the revised real cash flows. When the firms postpone recognizing the losses, the investments result would incur in the next financial reporting periods that could be out of the current managers' tenure. Therefore, accounting conservatism that is considered as a part of corporate control system can discourage the managers to invest the negative net present value projects or high risky positive NPV projects (Ball and Shivakumar,2005; Bushman et al.,2011).

Accounting conservatism can also mitigate the agency conflicts between the firms and the debt creditors. The debt lenders should evaluate the credit risks about the debt. If the borrowing firms have applied for the more conservative accounting reporting principles, there would be less credit risks involved with the debts because the accounting conservatism requires the firms timely to verify the bad news and to defer recognizing the good news. In other words, the potential losses would be recognized earlier than the gains. All these accounting treatments increase the borrowing firms' solvency. More prudent accounting reporting makes sure to pay the debt on time. Especially, when the firms are in financial constrained situations, accounting conservatism shows a good signal to the outside creditors because the borrowing firm engages in less risky and positive NPV projects (Lara, et al.,2016). Therefore, accounting conservatism can alleviate the financial constrains significantly (Zhang and Wang,2013). The agency cost of debt contracting could be reduced by the application of accounting conservatism (Watts,2013).

Agency cost due to the information asymmetric between the insiders and outsider is not only limited to the debt contracting but also to the equity financing. The firms' managers have incentive to overstate their firms' equity value in order to benefit their own interests. The manager can enjoy the upward stock price or stock option or larger firm size when the firms' equity prices go up. Accounting conservatism can play as an alternative corporate governance mechanism to prevent the myopic managerial activities that overvalue the firms' equity and assets (LaFond and Watts,2008).

In the literature, Hsu eta al. (2017) discuss the joint effect of accounting conservatism and the top manager overconfidence. To keep confidence in decisions is necessary for the top managers and it makes sure the top managers to become a good leader. However, overconfidence managers are more likely to engage in more risky investment or even negative NPV project. The prudent accounting reporting standard can mitigate the drawbacks of overinvestment decisions. Furthermore, Lara et al. (2016) also find that conservatism can improve the firms' investment efficiency.

\subsection{Hypothesis Development}

Business Strategy consists of three types: defenders, analyzers and prospectors. The defender's strategy makes the firms grow more stable. This kind of firms focus on improving internal operation efficiency. The prospector's strategy requires the firms to speed up the sales and market shares. The prospectors try to invest more in research and development expenditures. In the short time periods, the prospector's firms will apply much aggressive investment decisions for the purposes of maximizing the sales revenues. The analyzers are between the two extreme sides of defenders and prospectors. The prospectors always involve investing much in innovative techniques and aggressive operating behaviors. There would be myopic behavior in the process of applying for prospector strategies. These would lead to negative effects on the financial performance. This research believes that corporate governance and controlling factor can be applied for the mitigating the drawbacks of much more prospectors. The accounting conservatism can be chosen as an alternative governance and controlling factor. The accounting conservatism is designed by the country's government or some professional accounting organization. Many countries accounting principles include the accounting conservatism principle. It is a basic and important rule for standardizing the accounting treatment in order to solve the information asymmetric problems that commonly exists in financial reporting. The accounting conservatism requires the accounting treatment in an asymmetric way on the recognition of assets and liabilities or revenues and losses. The accounting conservatism can offset the risk that arouses from the more prospector strategy. Therefore, in this paper, the hypothesis is as follows: 
Hypothesis 1: The joint effect of business strategy and accounting conservatism is positively associated with financial performance.

$$
\begin{aligned}
\text { Perf }_{\mathrm{i}, \mathrm{t}}= & \alpha_{0}+\alpha_{1} \text { STRATEGY }_{\mathrm{i}, \mathrm{t}}+\alpha_{2} \text { CONSER }_{\mathrm{i}, \mathrm{t}}++\alpha_{3} \text { STA_CONSER }_{\mathrm{i}, \mathrm{t}}+\alpha_{4} \text { Size }_{\mathrm{i}, \mathrm{t}}+\alpha_{5} \mathrm{MB}_{\mathrm{i}, \mathrm{t}}+\alpha_{6} \text { Lev }_{\mathrm{i}, \mathrm{t}}+\alpha_{7} \text { Firm_Age }_{\mathrm{it}} \\
& +\alpha_{8} \text { EPS }_{\mathrm{it}}+\alpha_{9} \text { Year }_{\mathrm{it}}+\alpha_{10} \text { Industry }_{\mathrm{it}}+\varepsilon
\end{aligned}
$$

In the line of conservatism research, it is found that the firms' internal control quality is positively associated with accounting conservatism. This is because that the firms with better internal control quality would likely to apply for the accounting conservatism standards and implement the conservatism principle in daily accounting treatments to reduce the agency conflicts. In the material weakness (MW) firms, the accounting conservatism is found lower than the firms without material weakness (MW). When the material weakness (MW) firms improve their internal control quality, the accounting conservatism is also increased (Goh and Li, 2011). There are five components of internal control: control environment, risk assessment, control activities, information and communication and monitoring. Accounting conservatism can affect on the firm's operating activities with more prudence ways. Conservative accounting treatment can decrease the risk and increase the information disclosure. Therefore, the accounting conservatism can to some extent make up the negative effect of weak internal control quality. This research makes the following hypothesis:

Hypothesis 2: The joint effects of accounting conservatism and business strategy under different internal control quality would improve the firms' cash flows and firms' value.

\section{Sample and Measurement about the Main Variables}

\subsection{Sample Selection}

This research collects financial data from CSMAR database in China. The financial data includes the listed firms in Shanghai Stock Market and ShenZhen Stock Market. The internal control quality index is adapted from DIB database. The time period in this research is from 2008 to 2012. Any missing data variable is deleted from the dataset.

\subsection{Dependent Variable}

Perf is measured by the operating cash flow (OCF) divided by the sum of the future two years assets. This research wants to check whether any performance is influenced by the joint effects of business strategy and accounting conservatism. On the purpose of robustness test, the performance also equals to the total income (Perf_TIncome $)$ or net income (Perf_NetIncome).

\subsection{Testable Variable}

STRATEGY is the business strategy index based on the prior research of Miles and Snow $(1978,2003)$ and Bentley et al. (2013). STRATEGY reflects six characteristics of the firms: (a) the research and development costs scaled by the total sales, (b) the sales revenue growth rate, (c) the total number of the employees adjusted by the sales, (d) the selling, general \& administrative costs (SG\&A) scaled by the sales, (e) the standard deviation of the number of the employees and (f) the fixed assets to the total assets. Similar with Bentley et al. (2013) and Ittner et al. (1997), each variable is got by calculating a rolling average based on the previous 5 years. Each characteristic is ranked based on the quintile in each year. The highest quintile observation is scored as 5, the second quintile observation is scored as 4 , and so on, the lowest quintile observation is given as 1 . Each characteristic is scored from 1 to 5 . The total sum of 6 characteristics is the composite index for reflecting the business strategy. STRATEGY is measured from 1 to 30. The firm that has high level of STRATEGY score is defined as the prospectors, but the firm that has low level of STRATEGY score is named as the defenders.

CONSER_NOA is defined as the proxy of the unconditional accounting conservatism. This research follows Givoly and Hayn (2000) and Zhang and Wang (2013). It equals to the non-operating accruals (NOPAC) divided by the total assets and multiplied by -1 .

CONSER_score represents the level of conditional accounting conservatism. Following Basu (1997) and Khan and Watts (2009), CONSER_score is the decile rank average based on the sum of G-score (the firms' earnings timeliness to good news) and $\mathrm{C}$-score (the incremental earnings timeliness to bad news).

STA_CONSER_NOA is the joint effect of business strategy with unconditional accounting conservatism. It equals to STRATEGY multiplied by CONSER_NOA.

STA_CONSER_score represents the combination result of STRATEGY and CONSER_score. According to the hypothesis development, the research expects that the STA_CONSER_score shows the positive sign after making 
the regression analysis,

\subsection{Control Variable}

Size measures the firm's size that equals to the logarithm of total assets. $\boldsymbol{M B}$ shows the firm's value that is the market value over the book value of the firm. Lev measures the financial leverage and it equals to the total debts in year $t$ divided by the total assets in year t-1. Firm_Age shows the firm's age, the logarithm of firm's age. EPS reflects the firm's profitability, total earnings over the number of outstanding shares.

\subsection{Definition of Variable}

The dependent variable is $\boldsymbol{P e r f}$ that measures the financial performance. In the robustness test, the Perf is changed as the total income and net income. The independent variable includes STRATEGY, CONSER_NOA and CONSER_score. The testable variable is the joint effect of business strategy and accounting conservatism STA_CONSR_NOA and STA_CONSER_score. This paper also control the firm size market to book value、 financial debt ratio v firm age and shareholder interests (EPS). The details about the variable is defined in table 1:

Table 1. Variable Definition

\begin{tabular}{|c|c|c|}
\hline Variable & Explanation & Definition \\
\hline Perf & Performance & $\begin{array}{l}\text { Operating cash flows (OCF) divided by total assets in } \\
\text { future } 2 \text { years }\end{array}$ \\
\hline STRATEGY & Strategy & $\begin{array}{c}\text { A composite index covering } 6 \text { characteristics consist } \\
\text { with Bentley et al. (2013) and Ittner et al. (1997) } \\
\text { methods }\end{array}$ \\
\hline CONSER_NOA & Unconditional conservatism & NOPAC divided by total assets multiplied -1 \\
\hline CONSER_score & Conditional conservatism & $\begin{array}{l}\text { Decile rank of average based on the sum of G-score } \\
\text { and C-score }\end{array}$ \\
\hline STA_CONSER_NOA & $\begin{array}{l}\text { Joint effect of strategy and } \\
\text { unconditional conservatism }\end{array}$ & STRATEGY multiplied by CONSER_NOA \\
\hline STA_CONSER_score & $\begin{array}{c}\text { Joint effect of strategy and conditional } \\
\text { conservatism }\end{array}$ & STRATEGY multiplied by CONSER_score \\
\hline Size & Firms' Size & Logarithm of total assets \\
\hline $\mathrm{MB}$ & Market to Book Value & Market value divided by book value \\
\hline Lev & Financial Leverage & Total debt in year $\mathrm{t}$ divided by total asset in year $\mathrm{t}-1$ \\
\hline Firm_Age & Firm's age & Logarithm of firm's age \\
\hline EPS & Earnings per share & $\begin{array}{l}\text { Total earnings divided by the number of outstanding } \\
\text { shares }\end{array}$ \\
\hline
\end{tabular}

\section{Research Design and Results \\ 4.1 Descriptive Data}

The summary table shows the details about each variable. The number of firms is 6,566 . Some data is deleted due to the missing variable or extreme value. The Perf is from -9545.841 to 460.761. It reflects the firm performance varies a lot among different firms. STRATEGY is a composite index from 1 to 30 . This result is quite similar with other prior research about business strategy in China. For the CONSER_NOA, the minimum is -2.675 , the maximum is

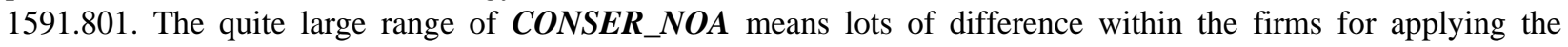


accounting conservatism. The standard deviation of CONSER_NOA is 30.696. Compared with CONSER_NOA, CONSER_score has much smaller standard deviation.

Table 2. Summary Table

\begin{tabular}{cccccc}
\hline Variable & No. & Mean & Std.Dev. & Min & Max \\
\hline Perf & 6,526 & 14.224 & 127.278 & -9545.841 & 450.761 \\
STRATEGY & 6,566 & 18.945 & 4.521 & 6.000 & 30.000 \\
CONSER_NOA & 5,087 & 0.874 & 30.696 & -2.675 & 1591.801 \\
CONSER_score & 6,058 & 0.027 & 0.188 & -13.304 & 5.288 \\
STA_CONSER_NOA & 5,087 & 17.604 & 614.001 & -50.816 & 30244.210 \\
STA_CONSER_score & 6,058 & 0.474 & 5.152 & -385.830 & 84.614 \\
Size & 6,565 & 21.466 & 1.390 & 10.842 & 28.857 \\
MB & 6,058 & 10.919 & 643.094 & 0.027 & 50000.00 \\
Lev & 6,356 & 0.544 & 3.050 & 0.007 & 142.718 \\
Firm_Age & 5,174 & 12.571 & 5.072 & 1.000 & 34.000 \\
EPS & 6,566 & 0.411 & 0.544 & -4.210 & 5.700 \\
\hline
\end{tabular}

\subsection{Correlation Analysis}

In the correlation table, the STRATEGY is negative correlated with Perf. This is the same as expected. The high aggressive strategy is not good for improving the financial performance. The similar relationship is for the CONSER and Perf.

Table 3. Correlation Analysis

\begin{tabular}{|c|c|c|c|c|c|c|}
\hline & Perf & STRATEGY & CONSER_NOA & CONSER_score & STA_CONSER_NOA & STA_CONSER_score \\
\hline Perf & 1.000 & & & & & \\
\hline STRATEGY & -0.063 & 1.000 & & & & \\
\hline CONSER_NOA & -0.022 & 0.016 & 1.000 & & & \\
\hline CONSER_score & -0.012 & -0.034 & -0.038 & 1.000 & & \\
\hline STA_CONSER_NOA & -0.020 & 0.018 & 0.996 & -0.054 & 1.000 & \\
\hline STA_CONSER_score & -0.007 & -0.015 & -0.040 & 0.986 & -0.057 & 1.000 \\
\hline Size & 0.056 & -0.233 & 0.003 & 0.031 & 0.000 & 0.060 \\
\hline MB & -0.006 & 0.039 & 0.043 & -0.911 & 0.060 & -0.963 \\
\hline Lev & -0.026 & 0.009 & 0.036 & -0.464 & 0.050 & -0.596 \\
\hline Firm_Age & 0.013 & -0.136 & 0.038 & 0.017 & 0.039 & 0.010 \\
\hline EPS & 0.189 & 0.147 & 0.011 & -0.030 & 0.010 & -0.013 \\
\hline
\end{tabular}

Table 4. Correlation Analysis

\begin{tabular}{cccccc}
\hline & Size & MB & Lev & Firm_Age & EPS \\
\hline Size & 1.000 & & & & \\
MB & -0.122 & 1.000 & & & \\
Lev & -0.115 & 0.785 & 1.000 & & \\
Firm_Age & 0.134 & -0.001 & 0.038 & 1.000 & \\
EPS & 0.242 & -0.011 & -0.044 & -0.089 & 1.000 \\
\hline
\end{tabular}




\subsection{Multivariate Regression Analysis}

In the table (4), the regression shows the joint effect of business strategy and accounting conservatism on financial performance. In the column (1), the dependent variable Perf is measured as OCF (Operating Cash Flows) divided by the average future two years assets. The variable STRATEGY is measured by 6 dimensions and in total 30 scores. The variable CONSER_NOA is defined as the unconditional accounting conservatism. This research focuses on the combination effects of business strategy and accounting conservatism. The joint effect is measured by the variable STA_CONSER_NOA that is the product of STRATEGY and CONSER_NOA. The research finds that the coefficient of STRATEGY is negative and significant on Perf at the significant level of 1\%. The coefficient of CONSER_NOA is also negative and significant $(p<0.1)$ on Perf. However, the variable STA_CONSER_NOA is positive and significant $(p<0.1)$ on Perf. These mean that STRATEGY and CONSER_NOA both have negative relationship with financial performance (Perf) separately, while the joint effect of STRATEGY and CONSER_NOA has positive relationship with financial performance $(\boldsymbol{P}$ erf $)$. The higher business strategy causes the firms to face much more uncertainty. Very strong accounting conservatism treatments lead to less investment. All of these would influence the negative financial performance. However, accounting conservatism plays a role similar as a kind of corporate governance mechanism and mitigate the drawback of business strategy of a firm. This can explain the reason that the combination of STRATEGY and CONSER_NOA make contribution on financial performance.

Table 4. Regression of Business Strategy on financial performance

\begin{tabular}{cc}
\hline & $(1)$ \\
VARIABLES & Perf \\
\hline STRATEGY & $-0.734 * * *$ \\
CONSER_NOA & $(0.136)$ \\
& $-0.382^{*}$ \\
STA_CONSER_NOA & $(0.200)$ \\
& $0.0174^{*}$ \\
Size & $(0.00981)$ \\
& 0.341 \\
MB & $(0.516)$ \\
Firm_Age & -0.000684 \\
& $(0.000740)$ \\
EPS & $0.245^{* *}$ \\
& $(0.117)$ \\
Year & $17.23^{* * *}$ \\
Industry & $(1.187)$ \\
Constant & Yes \\
Observations & Yes \\
Number of ID & $22.37 *$ \\
& $(12.66)$ \\
& 4,956 \\
& 1,471 \\
\hline
\end{tabular}

Standard errors in parentheses

$* * * \mathrm{p}<0.01, * * \mathrm{p}<0.05, * \mathrm{p}<0.1$

(Note: The variable Perf is already multiplied by 1000 on its original data in order to observe clearly.)

\section{Robustness Tests}

This research redefines the financial performance as the total income (Perf_TIncome $)$ and the net income (Perf_NetIncome) instead of the assets adjusted operating cash flows. In table 5, the testable variable STA_CONSER_score is the interaction of STRATEGY and CONSER_score. In column (1), the regression is to test 
the relationship between STA_CONSER_score and Perf_TIncome. The coefficient of STA_CONSER_score is 14.58 which is positive and significant $(\mathrm{p}<0.01)$ on Perf_TIncome. Similarly, in column (2), the coefficient of STA_CONSER_score is positive at the significant level of $1 \%$. Based on the regression results in column (1) and column (2), the higher scores of business strategy accompanying with much stricter accounting conservatism, the better financial performance will be. The result is in support of the research hypothesis.

Table 5. Regression of Business Strategy on alternative Perf variables

\begin{tabular}{ccc}
\hline & $(1)$ & $(2)$ \\
VARIABLES & Perf_TIncome & Perf_NetIncome \\
\hline STRATEGY & $-0.776^{* * * *}$ & $-0.740^{* * *}$ \\
CONSER_score & $(0.184)$ & $(0.182)$ \\
& $-389.7 * * *$ & $-386.2^{* * *}$ \\
STA_CONSER_score & $(42.58)$ & $(42.18)$ \\
& $14.58^{* * *}$ & $14.49^{* * *}$ \\
Size & $(2.390)$ & $(2.368)$ \\
& $-6.327^{* * *}$ & $-5.734 * * *$ \\
MB & $(0.629)$ & $(0.623)$ \\
& -0.00396 & -0.00353 \\
Firm_Age & $(0.00777)$ & $(0.00770)$ \\
& 0.0673 & 0.0386 \\
EPS & $(0.151)$ & $(0.149)$ \\
& $58.05^{* * *}$ & $53.23 * * *$ \\
Year & $(1.576)$ & $(1.562)$ \\
Industry & Yes & Yes \\
Constant & Yes & Yes \\
Observations & $149.0^{* * *}$ & $136.9 * * *$ \\
Number of ID & $(15.40)$ & $(15.26)$ \\
& 5,039 & 5,039 \\
& 1,486 & 1,486 \\
\hline
\end{tabular}

Standard errors in parentheses

$* * * \mathrm{p}<0.01, * * \mathrm{p}<0.05, * \mathrm{p}<0.1$

(Note: The variable Perf_TIncome and Perf_NetIncome are already multiplied by 1000 on its original data in order to observe clearly.)

\section{Further Analysis}

\section{Internal Control Quality}

Performance measured by total income (TIncome). This research further tests whether the positive relationship between STA_CONSER_score and Perf still exists after considering the internal control quality (ICQ). The ICQ can be classified into $\boldsymbol{L o w} \mathbf{I} \boldsymbol{C} \boldsymbol{Q}$ and $\boldsymbol{H i g h} \boldsymbol{I} \boldsymbol{C Q}$. The $\boldsymbol{L o w}_{-} \boldsymbol{I C Q}$ is any $\boldsymbol{I C Q}$ indicators that are less than 540.97 that is 25 percentiles of $\boldsymbol{I C Q}$. The $\boldsymbol{H i g h} \mathbf{I C Q}$ is any $\boldsymbol{I C Q}$ indicators that are more than 711.5 that is 75 percentiles of $\boldsymbol{I C Q}$. In table 6, this research exams the linear relationship between the variable STA_CONSER_score and Perf_TIcome under different levels of internal control quality. In column (1), under the lower internal control quality (Low_ICQ), the joint effect of business strategy (STRATEGY) and performance (Perf_TIncome) has a positive and significant influence on financial performance. The coefficient STA_CONSER_score is positive at the significant level of $10 \%$ $(\mathrm{p}<0.1)$. However, there is no such significant relationship based on the regression result in column (2). 
Table 6. Regression on Business Strategy on performance (Perf_TIncome) with different levels of internal control quality (ICQ)

\begin{tabular}{ccc}
\hline & $(1)$ & $(2)$ \\
VARIABLES & Perf_TIncome & Perf_TIncome \\
& 0.445 & High_ICQ $\boldsymbol{Q}$ \\
\hline STRATEGY & $(2.494)$ & -0.204 \\
CONSER_score & $-352.5^{* *}$ & $(0.190)$ \\
& $(150.5)$ & $-600.2^{* * *}$ \\
STA_CONSER_score & $14.58^{*}$ & $(160.3)$ \\
& $(8.521)$ & 1.471 \\
Size & 11.24 & $(8.191)$ \\
& $(9.817)$ & $-7.148^{* * *}$ \\
MB & 0.0104 & $(0.732)$ \\
& $(0.0287)$ & $0.766^{* * *}$ \\
Firm_Age & -0.552 & $(0.0929)$ \\
& $(2.368)$ & $0.322^{* *}$ \\
EPS & $178.5^{* * *}$ & $(0.145)$ \\
& $(16.46)$ & $26.42^{* * *}$ \\
Year & Yes & $(0.919)$ \\
Industry & Yes & Yes \\
Constant & -209.1 & Yes \\
Observations & $(241.9)$ & $186.1 * * *$ \\
Number of ID & 329 & $(17.89)$ \\
& 217 & 1,568 \\
& & 737 \\
\hline
\end{tabular}

Standard errors in parentheses

$* * * \mathrm{p}<0.01, * * \mathrm{p}<0.05, * \mathrm{p}<0.1$

(Note: The variable Perf_TIncome is already multiplied by 1000 on its original data in order to observe clearly.)

Performance measured by Net income (NetIncome). In table 7, the performance is measured by net income. This research finds the similar regression results in table 6 . When the firm has low internal control quality, the accounting conservatism can be applied as an alternative internal control factor. The relationship of STA_CONSER_score and Perf_NetIncome is positive and significant $(p<0.1)$. However, this kind of relationship cannot be found when the firm has higher internal control quality. The relationship of STA_CONSER_score and Perf_NetIncome is not significant. 
Table 7. Regression of Business Strategy on performance (Perf_NetIncome) with different levels of internal control quality (ICQ)

\begin{tabular}{|c|c|c|}
\hline VARIABLES & $\begin{array}{c}\text { (1) } \\
\text { Perf_NetIncome } \\
\text { Low_ICQ }\end{array}$ & $\begin{array}{c}(2) \\
\text { Perf_NetIncome } \\
\text { High_ICQ }\end{array}$ \\
\hline STRATEGY & $\begin{array}{c}0.411 \\
(2.501)\end{array}$ & $\begin{array}{c}-0.00823 \\
(0.154)\end{array}$ \\
\hline CONSER_score & $\begin{array}{c}-352.6 * * \\
(150.9)\end{array}$ & $\begin{array}{c}-435.6^{* * *} \\
(129.8)\end{array}$ \\
\hline STA_CONSER_score & $\begin{array}{l}14.61 * \\
(8.544)\end{array}$ & $\begin{array}{l}-4.421 \\
(6.643)\end{array}$ \\
\hline Size & $\begin{array}{c}11.24 \\
(9.844)\end{array}$ & $\begin{array}{c}-6.279 * * * \\
(0.588)\end{array}$ \\
\hline MB & $\begin{array}{c}0.0107 \\
(0.0288)\end{array}$ & $\begin{array}{c}0.462 * * * \\
(0.0745)\end{array}$ \\
\hline Firm_Age & $\begin{array}{l}-0.626 \\
(2.375)\end{array}$ & $\begin{array}{c}0.248 * * \\
(0.116)\end{array}$ \\
\hline EPS & $\begin{array}{c}177.7 * * * \\
(16.50)\end{array}$ & $\begin{array}{c}21.72 * * * \\
(0.747)\end{array}$ \\
\hline Year & Yes & Yes \\
\hline Industry & Yes & Yes \\
\hline Constant & $\begin{array}{l}-211.2 \\
(242.5)\end{array}$ & $\begin{array}{c}166.6^{* * * *} \\
(14.39)\end{array}$ \\
\hline Observations & 329 & 1,568 \\
\hline Number of ID & 217 & 737 \\
\hline
\end{tabular}

Standard errors in parentheses

$* * * \mathrm{p}<0.01, * * \mathrm{p}<0.05, * \mathrm{p}<0.1$

(Note: The variable Perf_TIncome is already multiplied by 1000 on its original data in order to observe clearly.)

\section{Conclusions}

The research emphasizes on whether the accounting conservatism can mitigate the negative effect of much more aggressive business strategies on performance. The research is based on the data originated from listed firms in China. The paper proves that the joint effect of business strategy and accounting conservatism is positively associated with financial performance. In the robustness tests, the paper gets the same conclusion. It also finds that the joint effect between business strategy and accounting conservatism matters for the financial performance when the firm has weak internal control quality.

Regards to the potential endogeneity problems, because the accounting conservatism is determined by the external factors, such as the government regulation and laws or accounting standards, etc., the firm's management cannot influence the accounting conservatism easily. In other words, the change of accounting conservatism is mainly relied on the exogenous shock (Cedergren, Lev, and Zarowin, 2015). Therefore, the possible endogenous effect between accounting conservatism and potential omitted variable is reduced. Second, Perf is got by adjusting the lagged two years assets. The interaction between STRATEGY and CONSER is positively related with financial performance. The result is robustness. 


\section{References}

Basu, S. (1997). The Conservatism principle and the asymmetric timeliness of earnings. Journal of Accounting and Economics, 49(1-2), 34-52. https://doi.org/10.1016/S0165-4101(97)00014-1

Bentley, K.A., T. Omer \& N.Y. Sharp (2013). Business strategy, financial reporting irregularities and audit effort. Contemporary Accounting Research, 30(2), https://doi.org/10.1111/j.1911-3846.2012. 01174. x

Bentley, K.A., N.J. Newton \& A.M. Thompson. (2017). Business strategy, internal control over financial reporting, and audit reporting quality. Auditing: A Journal of Practice \& Theory, 36(4), 49-69. https://doi.org/10.2308/ajpt-51693.

Bushman, R.M., J.D. Piotroski \& A.J. Smith. (2011). Capital allocation and timely accounting recognition of economic losses. Journal of Business Finance \& Accounting, 38, 1-33.

Chanderl, A.D. (1962). Strategy and structure: chapters in the history of the American Enterprise. MIT Press.

FASB. (2005). Board meeting handout: conceptual framework. Norwalk.CT. at: www.fasb.org/06-22-5.pdf.

Ittner, C.D., D.F. Larcker \& M.V. Rajan. (1997). The choice of performance measures in annual bonus contracts. The Accounting Review, 72(2), 231-55.

Lara, J.M.G., B.G. Osma \& F. Penalva. (2009). Accounting conservatism and corporate governance. Review of Accounting Studies, 14, 161-201. https://doi.org/10.1007/s11142-007-9060-1.

Givoly, D. \& C. Hayn. (2000). The changing time-series properties of earnings, cash flows and accruals: has financial reporting become more conservative? Journal of Accounting and Economics, 29(3), 287-320. https://doi.org/10.1016/S0165-4101(00)00024-0.

Goh, B.W. \& D.Li. (2011). Internal controls and conditional conservatism. The Accounting Review, 86(3), 975-1005. https://doi.org/10.2308/accr.00000041.

Higgins, D., T.C. Omer \& J.D. Phillips. (2015). The influence of a firm's business strategy on its tax aggressiveness. Contemporary Accounting Research, 32(2). https://doi.org/10.1111/1911-3846.12087.

Hsieh, C.C., Z.M. Ma \& K.E. (2019). Novoselov. Accounting conservatism, business strategy, and ambiguity. Accounting, Organizations and Society, 74, 41-55. https://doi.org/ 10.1016/j.aos/2018.08.001.

Hsu, C., K.E. Novoselov \& R.C. Wang. (2017). Does accounting conservatism mitigate the shortcomings of CEO overconfidence. The Accounting Review, 92(6),77-101.https://doi.org/10.2308/acc-51718.

LaFond, R. \& R.L. Watts. (2008). The information role of conservatism. The Accounting Review, 83(2), 447-478.https://doi.org/ 10.2308/accr.2008.83.2.447.

Lara, J. M.G., B.G. Osma \& F. Penalva. (2016). Accounting conservatism and firm investment efficiency. Journal of Accounting and Economics, 61, 221-238. https://doi.org/ 10.1016/j.jacceco.2015.05.003.

Liu, H. (2016). Does business strategy impact a firm's earnings property. Nankai Business Review, 19(4),111-121.

Miles, R.E., C.C. Snow, A.D. Meyer \& H.J. Coleman, JR. (1977). Organizational strategy, structure, and process. Academy of Management Review.

Miles, R.E. \& C.C. Snow. (1978). Organizational Strategy, Structure and Process. New York, NY: McGraw-Hill.

Miles, R.E. \& C.C. Snow. (2003). Organizational strategy, Structure, and Process. Stanford, CA: Stanford University Press.

Navissi, F., VG Sridharan, M. Khedmati, E.K.Y. Lim \& E. Evdokimov. (2017). Business strategy, over-(under-) investment, and managerial compensation. Journal of Management Accounting Research, 29(2), 63-86. https://doi.org/10.2308/jmar-51537.

Sun, J., B.Q. Wang, F. Cao \& X.Q. Liu. (2016). Does corporate strategy influence earnings management. Management World, (3), 160-169. https://doi.org/ 10.19744/j.cnki.11-1235/f.2016.03.013.

Sun, Y. \& W.H. Xu. (2012). The role of accounting conservatism in management forecast bias. Journal of Contemporary Accounting \& Economics, 8, 64-77. https://doi.org/ 10.1016/j.jcae.2012.05.002.

Wang, H.C., X.P. Zhang \& S.H. Gao. (2016). Does corporate strategy influence overinvestment. Nankai Business Review, 19(4), 87-97.

Watts, R.L. (2003a). Conservatism in accounting part I: explanation and implications. Accounting Horizons, 17(3), 
207-221. https://doi.org/ 10.2308/acch.2003.17.3.207.

Watts, R.L. (2003b). Conservatism in accounting part II: evidence and research opportunities. Accounting Horizons, 17, 287-301. https://doi.org/ 10.2308/acch.2003.17.4.287.

Yu, C., J.D. Eshleman \& J.S. Soileau. (2017). Business strategy and auditor reporting. Auditing: A Journal of Practice \&Theory, 36(2), 63-86. https://doi.org/10.2308/ajpt-51574.

Zhang, J.X. \& Y. Wang. (2013). Accounting conservatism and corporate financial constraints: conditional vs. unconditional conservatism. Accounting Research, (9), 44-50.

\section{Note}

Note 1. In 2015, IASB identified that the accounting conservatism should be the accounting information quality principle once again. 